\title{
Comment on "report of 5 novel mutations of the a-L-iduronidase gene and comparison of Korean mutations in relation with those of Japan or China in patients with mucopolysaccharidosis I"
}

Edina Poletto ${ }^{1,2^{*}}$, Ursula Matte $e^{1,2}$ and Guilherme Baldo ${ }^{1,2}$

\begin{abstract}
In this comment, we highlight that the IDUA pathogenic variants 704ins5 and c.613_617dupTGCTC are the same, but have different names depending on the nomenclature guideline used. Therefore, the frequency of this variant is $17.6 \%$ of alleles in Korean patients. This commentary stresses the importance of proper variant annotation and the use of guidelines when describing or reviewing mutations.
\end{abstract}

Keywords: IDUA, 704ins5, C.613_617dupTGCTC

\section{Background}

Ever since the IDUA ( $\alpha$-L-iduronidase) gene was first described [1], numerous pathogenic variants have been reported. However, the nomenclature guideline for human sequence variants has been updated over the years, and well known variants acquired new names. Since mutational profile studies frequently highlight differences in the allele frequencies in order to analyse and compare different populations, it is important to keep a sharp eye in the current guideline nomenclature, as it can influence the frequencies obtained and the conclusions of the study.

\section{Main text \\ 704ins5/c.613_617dupTGCTC}

In a paper published last year by Kwak and colleagues, "Report of 5 novel mutations of the $\alpha$-L-iduronidase gene and comparison of Korean mutations in relation with those of Japan or China in patients with Mucopolysaccharidosis I", a misunderstanding has been identified

\footnotetext{
* Correspondence: edinapoletto@gmail.com

${ }^{1}$ Postgraduate Program in Genetics and Molecular Biology, Universidade Federal do Rio Grande do Sul, Porto Alegre, Brazil

${ }^{2}$ Gene Therapy Center, Hospital de Clínicas de Porto Alegre, Ramiro Barcelos, 2350, Porto Alegre, RS 90035-903, Brazil
}

regarding the IDUA gene mutations 704ins5 and c.613_617dupTGCTC. The authors have considered them as two different mutations found in Korean patients with Mucopolysaccharidosis type I (MPS I), with frequencies estimated in approximately $12 \%$ and $6 \%$ of analysed alleles, respectively. We would like to point out that these mutations are the same and have different nomenclatures due to updates in nomenclature guidelines, which switched 704ins5 to c.613_617dupTGCTC, as appears in the Human Gene Mutation Database (HGMD) [2].

The mutation 704ins5 was first described in 1996 by Yamagishi and colleagues. In the original paper, it says the mutation was a duplication of a short sequence (CTGCT) and the position 704 was obtained considering the nucleotide 1 as the first of the cDNA sequence, not taking the translation initiation codon (ATG) into account. According to the current guidelines from the Human Genome Variation Society (HGVS - http://varnomen.hgvs.org), the nomenclature must follow prioritisation: duplication before insertion, most $3^{\prime}$ possible and cDNA considering position "c.1" as the A of the ATG start codon, and the the upstream regions considered as "c.-". Therefore, 704ins5 becomes c.613_617dupTGCTC, as illustrated in Fig. 1.

(c) The Author(s). 2018 Open Access This article is distributed under the terms of the Creative Commons Attribution 4.0 International License (http://creativecommons.org/licenses/by/4.0/), which permits unrestricted use, distribution, and reproduction in any medium, provided you give appropriate credit to the original author(s) and the source, provide a link to the Creative Commons license, and indicate if changes were made. The Creative Commons Public Domain Dedication waiver (http://creativecommons.org/publicdomain/zero/1.0/) applies to the data made available in this article, unless otherwise stated. 


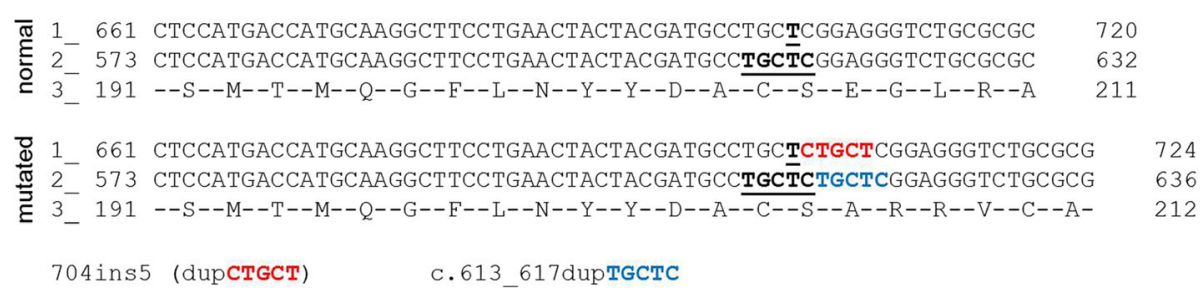

Fig. 1 Part of IDUA cDNA sequence obtained from Ensembl (www.ensembl.org, RefSeq NM_000203) highlighting mutation 704ins5/ c.613_617dupTGCTC. 1- Number refers to the nucleotide position considering number 1 as first nucleotide of cDNA (c.-88). 2- Number refers to the nucleotide position considering number 1 as the A from the first ATG (c.1). 3- Number refers to amino acid position considering number 1 as the first Methionine (p.M1). Black bold: positions 704 and 613_617 in line 1 and 2, respectively. Red: nucleotides inserted according to Yamagishi et al., 1996, when first describing mutation 704ins5. Blue: nucleotides duplicated in mutation c.613_617dupTGCTC. Both result in same nucleotide alteration, but were presented with different nomenclatures

\section{Conclusion}

In conclusion, since 704ins5 and c.613_617dupTGCTC are the same variant, its frequency in Korean patients is $17.6 \%$ of mutated alleles, being the second most frequent variant in MPS I patients in this population [3, 4], similar to what was observed in Japan, with $18.4 \%$ of alleles [5]. This commentary stresses the need for everyone involved in variant description, including authors, reviewers and readers alike, to bear in mind the importance of variant annotation and to use the most up-to-date guidelines.

\section{Abbreviations \\ HGMD: Human Gene Mutation Database; HGVS: Human Genome Variation Society; IDUA: a-L-Iduronidase; MPS I: Mucopolysaccharidosis type I}

\section{Funding}

Edina Poletto is recipient of a Conselho Nacional de Desenvolvimento

Científico e Tecnológico (CNPq) scholarship.

\section{Authors' contributions}

The manuscript was drafted and the final version approved by all authors.

Ethics approval and consent to participate

Not applicable.

\section{Consent for publication}

Not applicable.

\section{Competing interests}

The authors declare absence of competing interests.

\section{Publisher's Note}

Springer Nature remains neutral with regard to jurisdictional claims in published maps and institutional affiliations.

Received: 8 November 2017 Accepted: 25 September 2018

Published online: 04 October 2018

\section{References}

1. Scott HS, Guo XH, Hopwood JJ, Morris CP. Structure and sequence of the human alpha-L-iduronidase gene. Genomics. 1992;13(4):1311-3.

2. Stenson PD, Mort M, Ball EV, Shaw K, Phillips A, Cooper DN. The human gene mutation database: building a comprehensive mutation repository for clinical and molecular genetics, diagnostic testing and personalized genomic medicine. Hum Genet. 2014;133(1):1-9.

3. Kwak M, Huh R, Kim J, Park H, Cho S, Jin D. Report of 5 novel mutations of the a-Liduronidase gene and comparison of Korean mutations in relation with those of Japan or China in patients with mucopolysaccharidosis I. BMC Med Genet. 2016;17:58.

4. Lee IJ, Hwang SH, Jeon BH, Song SM, Kim JS, Paik KH, Kwon EK, Jin DK. Mutational analysis of the alpha-L-iduronidase gene in 10 unrelated Korean type I mucopolysaccharidosis patients: identification of four novel mutations. Clin Genet. 2004;66(6):575-6.

5. Yamagishi A, Tomatsu S, Fukuda S, Uchiyama A, Shimozawa N, Suzuki Y, Kondo N, Sukegawa K, Orii T. Mucopolysaccharidosis type I: identification of common mutations that cause hurler and Scheie syndromes in Japanese populations. Hum Mutat. 1996;7(1):23-9.
Ready to submit your research? Choose BMC and benefit from:

- fast, convenient online submission

- thorough peer review by experienced researchers in your field

- rapid publication on acceptance

- support for research data, including large and complex data types

- gold Open Access which fosters wider collaboration and increased citations

- maximum visibility for your research: over $100 \mathrm{M}$ website views per year

At BMC, research is always in progress.

Learn more biomedcentral.com/submissions 